\title{
Evaluating the Effect of N, P, K, S, Zn and B Fertilization on Growth, Yield and Yield Components of Maize (Zea mays L.) - A Review of Literatures
}

\author{
Habetamu Getinet \\ Ethiopian Institute of Agricultural Research, Debre Markos Agricultural Research Center, P.O.Box, 357, Debre \\ Markos, Ethiopia
}

\begin{abstract}
The presence of low soil fertility and poor plant nutrition does not only affect crop yields but also crop quality. This situation is happened whenever the soil is unable to satisfy the nutrient demand of a given crop and absence of documented information for each nutrients with their corresponding response on crop production. A review of many refereed published journal articles and books sourced from internet and libraries was conducted with the objective of highlighting the effects of nutrients on maize crop production and quality. More emphasis was focused on illustrating the functions through which various nutrient elements influence biochemical processes and eventually affect the overall quality of maize crops and their products. As a result nutrients reviewed in this paper included are nitrogen, phosphorus, potassium, sulfur, zinc and boron which show better response for maize. To optimize the nutrient demand of maize a number of research activities on mineral fertilizers have been emphasized. Accordingly, significant responses were observed at average of $100-200 \mathrm{~kg} \mathrm{ha}^{-1} \mathrm{~N}, 40-80 \mathrm{~kg} \mathrm{ha}^{-1} \mathrm{P}, 40-60 \mathrm{~kg} \mathrm{ha}^{-1}$ $\mathrm{K}, 20-40 \mathrm{~kg} \mathrm{ha}^{-1} \mathrm{~S}, 2-5 \mathrm{~kg} \mathrm{ha}^{-1} \mathrm{Zn}$ and $2.5 \mathrm{~kg} \mathrm{ha}^{-1} \mathrm{~B}$ for maize production. The crop parameters mostly affected by plant nutrition include: growth parameters, yield and yield-contributing characters with their response of each nutrients on maize are reviewed. It has noted that crop quality also greatly influenced by the synergistic and antagonistic interactions in various nutrients uptake and utilization. Therefore, balanced nutrition is noted to be of paramount importance not only boosting yield but also to maintain sustainability of soil health. To do so, it can concluded that identifying the contribution of each nutrient is a very important area to consider advancing and putting up resources for research since it has a huge bearing on human health and socioeconomic effect on farmers' incomes.
\end{abstract}

Keywords: Maize, Essential elements.

DOI: $10.7176 / \mathrm{JBAH} / 11-20-01$

Publication date:October $31^{\text {st }} 2021$

\section{Introduction}

Fertilizers are widely used in agriculture to maintain soil fertility and to increase crop yields, which are obtained from organic or inorganic material of natural or synthetic origin that is applied through soil or leaves to the plants to supply nutrients essential to the growth and productivity. When fertilizers apply in properly, they facilitated higher yields on less crop area than without the use of fertilizers; therefore, they are considered an important element in worldwide food production. As the population continues to grow, more and more agricultural output will be required, and fertilizers will play a vital role (Clark and Kelly, 2004).

Maize (Zea mays L.) is an important cereal crop grown widely in many countries of the world, which ranks the third after wheat and rice in the world (Belfield and Brown, 2008) and it is not only as a cereal but also as vegetable and fodder crop. Currently the yield and production of the crop, however, is under pressure from several constraints (Ferdu et al., 2001). Low soil fertility is widely considered as a major factor contributing to low productivity and non-sustainability of existing production systems (Mekuria et al., 2004). Nevertheless, its low level of maize production to agricultural point of view, very limited research literature is available on this specific aspect. However, comprehensive efforts have made to review the research work done in this regard along with maize by the eminent scientists and the available experimental findings have incorporated in this review paper. Growth and development of crop plants are directly related to their genetic constitution, though environmental factors and cultural practices do influence it through their direct and indirect impact on different metabolic process. Thus, agricultural production being consequence of an integrated interaction effect of soil-water fertilizer-climate continuum, which requires a wiseful and scientific management of this complex system, this is quite crucial for enhancing crop productivity on sustainable basis. Therefore, prompt effort is a must, not only to increase and stabilize crop production but also to enhance the nutrient use efficiency, which shows great influence on crop production. However, role of balanced and adequate nutrition is recognized as one of the important factors in realizing the maximum yield of maize. Besides, the major primary nutrients i.e. $\mathrm{N}, \mathrm{P}$ and $\mathrm{K}$, secondary nutrients like $\mathrm{S}$ and micronutrients $\mathrm{Zn}$ and $\mathrm{B}$ has recognized as essential inputs for sustained maize productivity and enhancement in its quality. Brief resume of research work relevant to the investigation entitled response of maize on growth, yield and quality of maize due to application of $\mathrm{N}, \mathrm{P}, \mathrm{K}, \mathrm{S}, \mathrm{Zn}$ and $\mathrm{B}$ has reviewed to evaluate the 
effects N, P,K,S, and micronutrients including Zn and B on growth parameters, yield and yield attributes of each nutrient on maize.

\section{Limiting Nutrients in Small holders for Maize Production}

Soil fertility declined in Sub-Saharan Africa (SSA) has contributed to the loss of major nutrients such as N, P and $\mathrm{K}$ (Tilahun, 2003). As a result, negative nutrient balances for these nutrients have found in smallholder farming systems. Hartemic et al. (2000) reported that $\mathrm{N}$ fertilizer input was required in order to sustain high crop yields in intensive crop production system. Further, $\mathrm{N}$ deficiency can amended through application of inorganic, organic fertilizer sources and biological $\mathrm{N}_{2}$ fixation. However, use of these inputs among smallholder farmers is currently very low.

According to Kwabiah et al. (2003), $\mathrm{P}$ is a limiting nutrient in maize production due to the low native soil $\mathrm{P}$ and high $\mathrm{P}$ fixation. This problem is aggravated due to $\mathrm{P}$ unlike $\mathrm{N}$ be replenished through biological fixation. To alleviate such problems, application of $\mathrm{P}$ from organic and inorganic sources is essential to sustain high crop yield. Further, he concluded that $\mathrm{P}$ deficiency was a factor limiting crop production in tropical and sub-tropical soils.

International center for research in agro forestry (ICRAF, 1997) found that $\mathrm{K}$ is an emerging limiting plant nutrient in humid and sub humid regions of Kenya. This attributed to greater losses than gains of soil nutrients leading to a negative balance in intensively cropped soils (Smaling et al., 1997). Potassium losses through leaching, soil erosion, runoff and crop uptake are higher than addition through weathering of parent material and application of organic and inorganic nutrient sources.

\section{Major nutrients affecting growth and yield of maize 3.1. Response of maize to Nitrogen}

Nitrogen is an essential nutrient for maize, which is consumed by the crop roots throughout the growing season. It is a vitally an important plant nutrient, the supply of which can be controlled trough proper management practices. In maize production, it is a major yield-determining factor and its availability in sufficient quantity throughout the growing season is essential for optimum maize growth (Kogbe and Adediran, 2003). Maize is soil stressful crop, which absorbs large amounts of nutrients in various stages of growth; especially $N$. Nitrogen enters in the composition of cells and is a basic element in the formation of amino acids that make up protein. Therefore, studies have shown that maize plants highly respond to $\mathrm{N}$ fertilizer. Yihenew in (2015) carried out a field experiment on Alfisols of Northwestern Ethiopia to determine the effect of N levels on maize. Majumdar et al. (2002) noticed that application of $100 \mathrm{~kg} \mathrm{ha}^{-1} \mathrm{~N}$ registered significantly higher plant height, functional leaves and dry matter accumulation. While working on fodder maize at Faisalabad (Pakistan), Ayub et al. (2003) reported that application of $120 \mathrm{~kg} \mathrm{ha}^{-1} \mathrm{~N}$ recorded the tallest plant, leaves plant ${ }^{-1}$ and stem diameter of maize over the control and $80 \mathrm{~kg} \mathrm{ha}^{-1} \mathrm{~N}$. One of the important things that make consuming more $\mathrm{N}$ component compared to rest elements by maize plant returns to its needed through all stages of growth (Lomer et al., 2012).

In case of yield and yield attributes worked by Choudhary et al. (2006), reported that increasing levels of $\mathrm{N}$ application rate up to $120 \mathrm{~kg} \mathrm{ha}^{-1} \mathrm{~N}$ significantly increased grain and fodder yield of maize. According to Bakht et al. (2006), significantly higher cobs plant ${ }^{-1}$, grains $\mathrm{cob}^{-1}$, grain and biological yield of maize were recorded with increasing levels of $\mathrm{N}$ application up to $200 \mathrm{~kg} \mathrm{~N} \mathrm{ha}^{-1}$. Similarly, significant enhancement in cob length and girth, grain weight $\mathrm{cob}^{-1}$, grain and stover yield of maize was reported with application of increasing levels of $\mathrm{N}$ up to $180 \mathrm{~kg} \mathrm{ha}^{-1} \mathrm{~N}$ (Ram et al., 2006). Significantly higher grain yield of maize was recorded with increasing levels of $\mathrm{N}$ application up to $120 \mathrm{~kg} \mathrm{~N}^{-1}$ (Meena et al., 2007a). Jan et al. (2007) reported significant increase in grain and stalk yield of maize to the $\mathrm{N}$ application as high as $300 \mathrm{~kg} \mathrm{ha}^{-1} \mathrm{~N}$. According to Kumar (2009) cob length, cob girth and with $\mathrm{N}$ application up to $80 \mathrm{~kg} \mathrm{ha}^{-1} \mathrm{~N}$ but cob girth continued to improve further with $\mathrm{N}$ application up to $120 \mathrm{~kg} \mathrm{~N} \mathrm{ha}^{-1}$.

Application of $\mathrm{N}$ in maize not only boost yield but also improve nutritional quality. Mishra et al. (2009) reported that application of increasing levels of $\mathrm{N}$ up to $200 \mathrm{~kg} \mathrm{~N} \mathrm{ha}^{-1}$ significantly increased protein content in maize grain. Carpici et al. (2010) observed significantly higher crude protein content with application of $400 \mathrm{~kg}$ $\mathrm{ha}^{-1} \mathrm{~N}$ over $200 \mathrm{kgha}^{-1} \mathrm{~N}$ but it remained at par with $300 \mathrm{~kg} \mathrm{ha}^{-1}$. Verma (2011) reported that protein content in maize grain significantly increased with increasing levels of $\mathrm{N}$ application rate up to $150 \mathrm{~kg} \mathrm{ha}^{-1}$. Mahdi et al. (2012) also noticed that application of $120 \mathrm{~kg} \mathrm{ha}^{-1} \mathrm{~N}$ significantly increased crude protein; protein yield and crude fiber content over $90 \mathrm{~kg} \mathrm{ha}^{-1} \mathrm{~N}$. Similarly, Jeet et al. (2012) also reported that protein content in grain of maize increased significantly with increasing doses of $\mathrm{N}$ up to $150 \mathrm{~kg} \mathrm{ha}^{-1}$. In general, numerous studies have shown that maize grain yield was increased due to $\mathrm{N}$ fertilizer application. According to (Gagnon et al., 2012), $\mathrm{N}$ application at various rates in field studies conducted across Canada significantly increased maize yield and $\mathrm{N}$ uptake. Indeed, the magnitude of maize response to $\mathrm{N}$ was influenced by crop rotation, soil mineral $\mathrm{N}$ content at planting, soil organic matter content, topography, clay content, soil drainage, and water availability. Hence, $\mathrm{N}$ fertilizer recommendations that do not consider these important factors may lead to over or under fertilization with environmental and economic problems (Ladha et al., 2005). Thus, improved management practices in agricultural 
production systems are fundamental for optimizing crop yield, minimizing $\mathrm{N}$ loss and increasing $\mathrm{N}$ uptake efficiency. This includes synchronizing $\mathrm{N}$ fertilizer supply with crop $\mathrm{N}$ demand through appropriate timing, rate, and method of application, as well as using split applications based on chlorophyll levels in the leaf and $\mathrm{N}$ concentration in the plant (Qiu et al., 2015). The success of these management practices requires an accurate estimation of the fertilizer $\mathrm{N}$ rate that provides the highest crop yield at which optimum economic returns can also achieved by the farmers.

\subsection{Response of Maize to Phosphorus}

Phosphorus is an essential plant nutrient, which involves in all physiological activities of the crop production. Adequate $\mathrm{P}$ nutrition enhances many aspects of plant physiology, including the fundamental processes of photosynthesis, root growth particularly development of lateral roots and fibrous rootlets (Gebreslassie and Hailemariam, 2016). A field experiment was done by Rasheed et al. (2004) who noticed that significantly taller plants, higher flag leaf area and days to silking with application of $60 \mathrm{~kg} \mathrm{ha}^{-1} \mathrm{P}$ was obtained compared over control. Jena et al. (2015) working on quality protein maize who reported that application of $100 \mathrm{~kg} \mathrm{ha}^{-1} \mathrm{P}$ produced taller plant and LAI over rest of the P levels (i.e. 0, 60 and $80 \mathrm{~kg} \mathrm{ha}^{-1}$ ).

In case of yield and yields attributes an experiment was done at New Delhi, by Arya and Singh (2000) to determine the response of maize to different levels of $\mathrm{P}\left(0,30,60\right.$ and $\left.90 \mathrm{~kg} \mathrm{ha}^{-1} \mathrm{P}_{2} \mathrm{O}_{5}\right)$ and reported significantly higher grain and stover yield was obtained with application of increasing levels of $\mathrm{P}$ up to $90 \mathrm{~kg} \mathrm{ha}^{-1} \mathrm{P}_{2} \mathrm{O}_{5}$. The magnitude of increase in grain and stover yield was 17.2, 54.4 and 82.3\% and 6.5, 37.3 and 59.6\% with application of 30, 60 and $90 \mathrm{~kg} \mathrm{P}_{2} \mathrm{O}_{5}$ ha $^{-1}$ over control, respectively. Similarly, Shivran et al. (2013) reported that significantly higher grain and stover yield of maize was recorded due to increasing the level up to $40 \mathrm{kgha}^{-1} \mathrm{P}_{2} \mathrm{O}_{5}$. Application of $\mathrm{P}$ to the soil not only increase yield and yield attributes but also it enhances the uptake of other nutrients including $\mathrm{N}, \mathrm{K}$ and $\mathrm{S}$. Application of increasing levels of $\mathrm{P}$ up to $90 \mathrm{~kg} \mathrm{ha}^{-1} \mathrm{P}_{2} \mathrm{O}_{5}$ significantly increased $\mathrm{N}, \mathrm{P}$ and $\mathrm{K}$ uptake in maize (Arya and Singh 2000). According to Venkatesh et al. (2002), application of increasing levels of $\mathrm{P}$ up to $60 \mathrm{~kg} \mathrm{ha}^{-1} \mathrm{P}_{2} \mathrm{O}_{5}$ recorded significantly higher $\mathrm{P}$ uptake in maize.

\subsection{Response of Maize to Potassium}

Potassium is another macronutrient required for crop growth and activates a number of enzymes, including those involved in the synthesis of carbohydrates and resistance to diseases and adverse environmental conditions. It also improves the utilization of $\mathrm{N}$ and $\mathrm{P}$ and plays an important role in growth and reproductive development of plants. Asif et al. (2007) carried out a field experiment at Peshawar, Pakistan to study the penology and leaf area of spring maize to different levels of $\mathrm{K}\left(0,30,60\right.$ and $\left.90 \mathrm{~kg} \mathrm{ha}^{-1}\right)$ and reported that tasseling, silking and physiological maturity were delayed when $\mathrm{K}$ application was increased up to $60 \mathrm{~kg} \mathrm{ha}^{-1}$, while increase in $\mathrm{K}$ level up to $90 \mathrm{~kg}$ $\mathrm{ha}^{-1}$ significantly enhanced tasseling, silking and maturity as well as flag leaf area and leaf area. Similarly, Amanullah et al. (2015) conducted a field experiment at Peshawar, Pakistan who reported that among the foliar K levels, plant height, mean single leaf area and LAI were obtained were recorded with the application of $2 \%$ foliar spray.

Potassium involves yield and yield attributes of maize where Kalpana and Krishnarajan (2002) reported that significantly higher cobs plant ${ }^{-1}$, cob length, cob width and stover yield of baby corn was recorded due to application of $50 \mathrm{~kg} \mathrm{ha}^{-1} \mathrm{~K}$ as compared to $40 \mathrm{~kg} \mathrm{ha}^{-1} \mathrm{~K}$. Amanullah et al. (2015) also revealed that among the foliar K levels, 1000-grain weight, No. of grains ear $^{-1}$ and harvest index were obtained from application of $2 \%$ foliar spray, whereas, the highest grain yield and shelling percentage was recorded with the foliar spray of $\mathrm{K}$ at $3 \%$. Maize is relatively sensitive to $\mathrm{K}$ deficiency where maturity date delayed, ears are smaller when $\mathrm{K}$ is deficient while the stalks are weak and lodging is common. However, it has given less attention than $\mathrm{N}$ and $\mathrm{P}$ with respect to increasing cereal production because the effect of it on increasing cereal production is more gradual compared with $\mathrm{N}$ and $\mathrm{P}$ especially in K-enriched soils (Tan et al., 2012). Effective $\mathrm{K}$ fertilization is therefore important during plant production as it results into defined qualitative parameters (Niu et al., 2013).

\subsection{Response of Maize to Sulfur}

Sulfur is often the third limiting nutrient in the soil after $\mathrm{N}$ and $\mathrm{P}$, yet it is seldom included in the fertilizers commonly available (Randhawa and Arora, 2000). It is known to be indispensable for many reactions in all living cells. A field experiment on maize was conducted where application of increasing levels of sulfur up to $40 \mathrm{~kg} \mathrm{ha}^{-}$ ${ }^{1}$ significantly enhanced plant height, number of green leaf plant ${ }^{-1}$, leaf area index and dry matter of maize as reported by (Sakal et al., 2000). Similarly, Ram et al. (2006) also reported that plant height, leaf area index and dry matter production of maize increased significantly with increasing levels of sulfur up to $60 \mathrm{~kg} \mathrm{ha}^{-1}$.

With regard to yield and yield attributes, Srinivasarao et al. (2010) noticed that increasing levels of sulfur up to $20 \mathrm{~kg} \mathrm{ha}^{-1}$ significantly increased cob length, cob girth, cob weight, grain and stover yield. At Varanasi working on quality protein maize hybrid, Jeet et al. (2012) reported that cobs plant ${ }^{-1}$, cob length, grain and stover yield significantly increased with increasing levels of sulfur rates up to $45 \mathrm{~kg} \mathrm{ha}^{-1}$. Shivran et al. (2013) also reported 
that significantly higher grain and stover yield of maize was obtained with increasing levels of sulfur application up to $60 \mathrm{~kg} \mathrm{ha}^{-1}$. From quality point of view, it is an essential nutrient, which is a component of some proteins and glycosides that are the source for the characteristic odors of some plants. According to Srinivasarao et al. (2010), increasing levels of sulfur application up to $20 \mathrm{~kg} \mathrm{ha}^{-1}$ significantly increased crude protein content in maize. Similarly, Jeet et al. (2012) working on quality protein maize noticed significantly higher protein content was observed at rate of $45 \mathrm{~kg} \mathrm{ha}^{-1}$.

\section{Importance of Micronutrients for Maize growth and Production}

Micronutrients play an active role in plant metabolism process starting from cell wall development to respiration, photosynthesis, chlorophyll formation, enzyme activity and $\mathrm{N}$ fixation and reduction. Micronutrient requirements of maize is relatively small and ranges between their deficiencies and toxicities in plants and soils are rather narrow (Brady and Weil, 2002). Expectation of higher maize productivity with adequate amount of fertilizer nutrients may lead to become limiting to some micronutrients in the soil and most times due to their over mining by the crops and shortage of which often show the deficiency symptoms and yields reduced.

The decline of micronutrients from the soil and their uptake by plants to such critical level, which shows their deficiency symptoms to different crops and in shortage produce low yields. This occurred due to expectation of higher maize production using adequate amount of fertilizer nutrients, which may lead limitation of some micronutrients in the soil (Das, 2000). Soil nutrient mining remains a challenge in smallholder farmers' fields where secondary and micronutrients are removed without replacement (Alley and Vanlauwe, 2009).

\subsection{The role of Zinc on growth of maize}

Zinc involved from very simple to very complex reactions in the plant system by influencing the activities of hydrogenase and carbonic anhydrase and stabilization of ribosomal proteins (Tisdale, 1984). It activates the plant enzymes by carbohydrate metabolism, maintaining the integrity of cellular membranes, protein synthesis and regulation of auxin synthesis. In addition, it is required for regulation and maintenance of the gene expression to induce tolerance of environmental stresses in plants (Cakmak, 2000). In crop plant $\mathrm{Zn}$ is absorbed in form of $\mathrm{Zn}^{2+}$ cation and is highly determined by soil $\mathrm{pH}$, and variability in its uptake was $98 \%$ due to increase in soil $\mathrm{pH}$.

Amongst crops, maize shows high sensitivity to zinc deficiency for its physiological requirements (Marschner, 1995). In addition, nitrogen integrated with zinc improved plant height and yield in maize (Xia et al., 2004). A study conducted in Pakistan indicates that the mean grain yield of maize was significantly increased by adding $2.75 \mathrm{~kg} \mathrm{ha}^{-1} \mathrm{Zn}$ to the soil resulted in an additional $720 \mathrm{~kg} \mathrm{ha}^{-1}(25 \%)$ of grain. Total dry matter of cobs ha-1 and cob weight ha ${ }^{-1}$ were all significantly increased following application of $2.75 \mathrm{~kg} \mathrm{ha}^{-1} \mathrm{zinc}$ as reported by (Harris et al., 2007). Therefore, in areas where intensive cultivation is practiced integrated application of zinc with major macronutrients has become a regular feature in maize cultivation.

\subsection{The role of Boron on growth of maize}

Boron is an essential element for better utilization of major macronutrients and there by greater translocation of photo-assimilates from source to sink during growth period. It is also plays an important role in the transport of sugars across cell membranes and in synthesis of cell wall material. It influences transportation through the control of sugar and starch formation (Singh et al., 2015). There is a considerable yield reduction in maize when the soil boron content is low (Rashid, 2006) and he estimated a substantial potential net economic benefit from the use of boron fertilizers in deficient soils. Hence, its deficiency has realized as the second most important micronutrient constraint in crops after zinc.

\section{Conclusion}

It is concluded that comparative use of N, P, K, S, Zn and B improved yield and quality of maize. The optimized dose of these nutrients also depicted in enhancing the yield as well as advantageous to the growers. Efficient use of balanced nutrients either from chemical, or organic sources has been proven to be beneficial for maize production in terms of yield, nutritional value and net profitability. Fertility management plays a key role in maize production and it exhibit full potential only when supplied with adequate quantities of nutrients at proper time. This is particularly important in achieving the higher yield and for maintaining the soil fertility. Hence, the longterm evaluation of experimental results is pertinent for sustainability of maize production.

\section{References}

1. Adediran J. A. and J. O. Kogbe. 2003. Influence of nitrogen, phosphorus and potassium application on yield of maize in the savanna zone, Nigeria. African Journal of Biotechnology. 2: 345-349.

2. Alley M. and Vanlauwe B. 2009. The role of fertilizers in Integrated Plant Nutrient Management. $1^{\text {st }}$ edition, Paris, $59 \mathrm{pp}$.

3. Amanullah, A., Iqbal, A., \& Iqbal, M. (2015). Impact of potassium rates and their application time on dry 
matter partitioning, biomass and harvest index of maize (Zea mays) with and without cattle dung application. Emirates Journal of Food and Agriculture, 447-453.

4. Ayub, M., Ahmad, R., Nadeem, M.A., Ahmad, B. and Khan, R.M.A. 2003. Effect of different levels of nitrogen and seed rates on growth, yield and quality of maize. Pak. J. Agri. Sci., 40:140-142.

5. Bakht, J., Ahmad, S., Tariq, M., Habib, A. and Shafi, M. 2006. Response of maize to planting methods and nitrogen fertilizer. J. Agric. Bio. Sci., 1: 8-14.

6. Belfield S. and Brown C. (2008).Field Crop Manual: Maize. A Guide to Upland Production in Cambodia. NSW Department of Primary Industries.2008. ISBN 978073471882 2. Belfield, S. and Brown C. (2008). Field Crop Manual: Maize. A Guide to upland production in Cambodia NSW Department of Primary Industries.pp.7-8.

7. Brady N C. and Weil R. 2002. Micronutrient and other trace elements. The Nature and Property of Soil (13 ${ }^{\text {th }}$ edition). Pearson Education Publisher, Singhapur, 638- 668 pp.

8. Cakmak I. 2000. Possible roles of zinc in protecting plant cells from damage by reactive oxygen species. 146:185-205.

9. Carpici, E.B., Celik, N. and Bayram, G. 2010. Yield and quality of forage maize as influenced by plant density and nitrogen rate. Turk. J. Field Crops, 15:128-132.

10. Das D.K. 2000. Micronutrients: their behavior in soils and plants. Kalyani Publishers', New Delhi, India, pp. 307.

11. Ferdu A., Demissew K. and Birhane A. 2001. Major insect pests of maize and their management. In Enhancing the Contribution of Maize to Food Security in Ethiopia: Proceedings of the second national maize workshop of Ethiopia: International Maize and Wheat Improvement Center and Ethiopian Agricultural Research Organization Addis Ababa, Ethiopia. pp. 89-90

12. Gagnon B., Ziadi N. and Grant C. 2012. Urea fertilizer forms affect grain corn yield and nitrogen use efficiency. Canada Journal of Soil Science. 92: 341-351.

13. Gebreslassie H., Berhane and Haile Mariam A. 2016. A Review on Effect of Phosphorus Fertilizer on Crop Production in Ethiopia. Journal of Biological Agriculture Healthcare, 6(7), pp.117-120.

14. Harris D., Rashid A., Miraj.G G., Arif M. and Shah H. 2007. On-farm seed priming with zinc sulfate solution: A cost-effective way to increase the maize yields of resource poor farmers. Field Crops Research, (102): $119-127$.

15. ICRAF. 1997. International centre for research in Agro forestry. Nairobi Kenya. Annual report 1997.

16. Jan, A., Aslam, I.K., Akber, H. and Khan, G.D. 2007. Yield potential of maize hybrid under intensive input management. Sarhad J. Agric., 23: 31-34.

17. Jeet, S. 2012. Effect of nitrogen and sulfur levels on growth and yield of quality protein maize (Zea mays L.) hybrids under dry land condition.

18. Kalpana R. and Krishnarajan J. 2002. Effect of dose and time of potassium application on yield and quality of baby corn. Journal of Agricultural Science. 22:59-60.

19. Kumar, A. 2009. Influence of varying plant population and nitrogen levels on growth, yield, economics and nitrogen use efficiency of popcorn (Zea mays Everta). Crop Res., 37:19-23.

20. Kwabiah A.B., Stoskopf N.C., Palm C.A., Voroney R.P., Rao M.R. and Gacheru E. 2003. Phosphorus availability and maize response to organic and inorganic fertilizer inputs in a short term study in Western Kenya. 95: pp. 49-59.

21. Ladha JK, Pathak H., Krupnik TJ, Six J. and Kessel C. 2005. Efficiency of fertilizer nitrogen in cereal crop production: Retrospect's and prospects. Advanced Agrononomy. 87: 85-156.

22. Lomer A.M., Ali-zade V. Chogan R. and Amiri E. 2012. Effect of nitrogen on the growth levels and development of maize hybrids in the condition of amino acids application. Institution Journal of Agriculture in Crop Science, 4 (14), 984-992

23. Mahdi, S.S., Hasan, B. and Singh, L. 2012. Influence of seed rate, nitrogen and zinc on fodder maize (Zea mays L.) in temperate conditions of western Himalayas. Indian J. Agron., 57:85-88.

24. Majumdar, B., Venkatesh, M.S., Kumar, K. and Patiram. 2002. Effect of nitrogen, sulfur and pig manure application on yield, nutrient uptake and quality parameters of maize-mustard crop rotation and residual nutrient buildup in an acidic Alfisols of Meghalaya. J. Hill Res., 15:63-70.

25. Marschner H. 1995. The soil root interface (rhizosphere) in relation to mineral nutrition. Mineral nutrition of higher plants. pp. 889.

26. Meena, O., Khafi, H.R., Shekh, M.A., Mehta, A.C. and Davda BK. 2007a. Effect of vermicompost and nitrogen on content and yield of rabi maize. Crop Res., 33: 53-54.

27. Mekuria Mulugeta, Waddington SR. and Siziba S. 2004. Breaking the fertilizer poverty and food insecurity traps in smallholder maize based systems in southern Africa: experiences and lessons from Soil Fertility Network. In: African Association of Agricultural Economists. Shaping the future of African agriculture for development: the role of social scientists. Proceedings of the Inaugural Symposium, Nairobi, Kenya, pp.6-8 
28. Mishra, B.N., Yadav, R.S., Rajput, A.L. and Pandey, M. 2009. Effect of plant geometry and nitrogen application on yield and quality of winter maize (Zea mays L.). Indian J. Agron., 39:468-469.

29. Niu J., Zhang W., Chen X., Li, C., Zhang F., Jiang L., Liu Z., Xiao K., Assaraf M. and Imas P. 2013. Potassium fertilization on maize under different production practices in the North China. Journal of Agronomy, 103: 822- 829

30. Qiu SJ, He P, Zhao SC, Li WJ, Xie JG, Hou YP, Grant CA, Zhou W. and Jin JY. 2015. Impact of nitrogen rate on maize yield and nitrogen use efficiencies in northeast China. Journal of Agronomy, 107: 305-313.

31. Ram, V., Singh, R.N. and Singh, K. 2006. Studies on integrated use of FYM, nitrogen and sulphur on growth, yield attributes and yield on winter maize (Zea mays L.). Plant Archi., 6:749-752.

32. Randhawa P.S and Arora C.L. 2000. Phosphorus - Sulfur interaction effects on dry matter yield and nutrient up take by wheat. Journal of Indian Society of Soil Science. 48(3): 536-540.

33. Sakal, R., Sinha, R.B., Singh, A.P., Bhogal, N.S. and Ismail, M.D. 2000. Influence of sulfur on yield and mineral nutrition of crops in maize-wheat sequence. J. Indian Soc. Soil Sci., 48:325-329.

34. Shivran, R.K., Kumar, R. and Kumari, A. 2013. Influence of sulfur, phosphorus and farm yard manure on yield attributes and productivity of maize (Zea mays L.) in humid south eastern plains of Rajasthan. Agric. Sci. Digest, 33:9-14.

35. Smaling E.M.A., Nandwa S.M. and Janssen B.H. 1997. Soil fertility is at stake. In replenishing soil fertility in Africa. American Society of Agronomy and Soil Science Society, pp. 47-61.

36. Srinivasarao, C., Ali, M., Venkateswarlu, S., Rupa, T.R., Singh, K.K., Kundu, S. and Prasad, J.V.N.S. 2010. Direct residual effects of integrated sulfur fertilization in maize (Zea mays)-chickpea (Cicer arietinum) cropping system on Typic Ustochrept. Indian J. Agron., 55:259-263

37. Tan D., Jin J., Jiang L., Huang S. and Liu Z. 2012. Potassium assessment of grain producing soils in north China. Agricultural Ecosystem Environment, 148: 65-71.

38. Tilahun A. 2003. Opportunities and Challenges in Reversing Land degradation: The Regional Experience. Natural resource degradation and environmental concerns in the Amhara National Regional State: Impact on Food Security. Ethiopian Soils Science Society. (3): 173-183.

39. Tisdale S.L., Nelson W.L. and Beaten J.D. 1984. Zinc in soil fertility and fertilizers. $4^{\text {th }}$ edition, New York: Macmillan Publishing Company.

40. Verma, N.K. 2011. INM in winter maize (Zea mays L.) sown at different dates. J. Plant Bree. Crop Sci., 3:161-167.

41. Xia L.H., Zhong H.M., Wang D.R., Wang H., Zhou W.L. and Gu, Y.X. 2004. Effect of mixed application of nitrogen and zinc fertilizers on yield increase of summer maize. Journal of Jilin Agricultural University, 26, 538-541.

42. Yihenew G. 2015. The effect of nitrogen fertilizer rates on agronomic parameters, yield components and yields of maize grown on Alfisols of Northwestern Ethiopia. Environmental System Research, 4(1): 1-7. 